\title{
DETERMINASI MOLEKULER KOI HERPES VIRUS (KHV) YANG DIISOLASI DARI IKAN KOI (Cyprinus carpio koi)
}

\author{
(Molecular Determination of Koi Herpes Virus (KHV) Isolated \\ from Koi Fish (Cyprinus carpio koi))
}

\author{
Jetti Treslah Saselah ${ }^{1}$, Reiny A. Tumbol ${ }^{2}$, Henky Manoppo ${ }^{2}$ \\ ${ }^{1}$ Program Pascasarjana, Universitas Sam Ratulangi, Manado, Sulawesi Utara. \\ ${ }^{2}$ Fakultas Perikanan dan Ilmu Kelautan Universitas Sam Ratulangi, Manado, Sulawesi Utara.
}

Penelitian ini bertujuan untuk mendeterminasi keberadaan Koi Herpes Virus (KHV) pada ikan koi (Cyprinus carpio koi). Sampel ikan diambil dari Kabupaten Kepulauan Sangihe. Penelitian di lakukan di Laboratorium Biologi Fakultas Matematika dan Ilmu Pengetahuan Alam Universitas Sam Ratulangi dengan menggunakan metode Polymerase Chain Reaction (PCR). Hasil pemeriksaan PCR terhadap sampel ikan koi mengindikasikan bahwa sampel ikan koi telah terinfeksi oleh vỉrus KHV, yang ditandai dengan munculnya pita DNA pada hasil visualisasi elektroforesis agarosa. Hasil pemeriksaan pada morfologi ternyata sampel ikan yang digunakan menunjukkan gejala-gejala klinis terserang KHV seperti mata pucat, insang berwarna pucat serta produksi lendir yang berlebihan Beberapa sampel lainnya walaupun secara morfologi belum menunjukan gejala-gejala klinis tetapi melalui pemeriksaan PCR telah terindikasikan terinfeksi KHV.

Kata kunci: $K H V, P C R$, ikan koi

The purpose of this study was to determine the presence of Koi Herpes Virus (KHV) in Koi (Cyprinus carpio koi). Fish samples were taken from the Sangihe Archipelago Regency. Laboratory work conducted at the Laboratory of Biology Faculty of Mathematics and Natural Sciences University of Sam Ratulangi using Polymerase Chain Reaction (PCR) method. The samples indicated that the koi fish samples were infected with KHV. It is shown by the appearance of DNA bands on agarose electrophoresis visualization. The morphological examination of the body indicated clinical symptoms of KHV infection, such as pale eyes, pale gills and excessive mucus production. Several other samples, although without clinical symptoms, have shown to be infected as indicated by PCR test.

Keywords: $K H V, P C R$, Koi.

\section{PENDAHULUAN}

Ikan Koi (Cyprinus carpio koi) merupakan jenis ikan hias air tawar yang bernilai ekonomis penting. Pengembangan budidaya ikan koi di daerah Sulawesi Utara telah diikuti pula oleh perkembangan penyakit terlebih khusus penyakit yang menyerang secara spesifik ikan koi dan ikan mes yang di duga disebabkan oleh penyakit KHV (Koi Herpes Virus). Serangan penyakit KHV baik pada ikan koi maupun ikan mas di daerah ini telah membawa kerugian yang cukup berarti.

KHV merupakan salah satu contoh jenis virus yang menyerang family Cyprinid, yang awalnya ditemukan pada tahun 1996 di Inggris. Virus ini dapat menular dengan cepat dan dapat menyebabkan kematian secara masal pada golongan ikan family Cyprinid seperti ikan mas (Cyprinus carpio) dan koi (Cyprinus carpio koi) (Hendrick et al., 2000; Perelberg et al., 2003; Sunarto et al., 2005). Wabah KHV telah menye- rang beberapa negara seperti Israel, Amerika Serikat, beberapa negara Eropa, Afrika Selatan, China, Taiwan dan Jepang dan Indonesia (Haenan et al., 2004).

Penyebaran penyakit ini telah melintasi hampir semua daerah budidaya ikan mas di Indonesia. Hal ini sesuai dengan data daerah yang telah terserang KHV berdasarkan Keputusan Menteri Kelautan Dan Perikanan Nomor: KEP. 03/MEN/2010 tentang jenis-jenis hama dan penyakit ikan karantina, golongan, media pembawa dan sebarannya.

Kajian tentang KHV juga telah dilakukan oleh beberapa peneliti di beberapa sentra budidaya di Sulawesi Utara. Sebagian besar sampel yang digunakan ialah ikan mas, sedangkan ikan koi hanya beberapa sampel. Hasil penelitian yang ada hanya berupa laporan kejadian, sampai tahapan deteksi dengan menggunakan metode Polymerase Chain Reaction (PCR). PCR merupakan suatu teknik pemeriksaan yang telah dikembangkan untuk mendiagnosis berba- 
gai penyakit infeksi virus termasuk untuk deteksi keberadaan KHV pada ikan mas dan ikan koi (Mudjiutami, et al., 2009).

Berdasarkan beberapa faktor di atas, maka dipandang perlu melakukan penelitian yang lebih detail tentang determinasi molekuler KHV pada ikan koi.

\section{METODE PENELITIAN}

\section{Lokasi Penelitian}

Penelitian ini menggunakan sampel yang diambil dari Kabupaten Kepulauan Sangihe. Analisis laboratorium dilakukan di Laboratorium Biologi Fakultas Matematika dan Ilmu Pengetahuan Alam, Universitas Sam Ratulangi Manado.

\section{Materi Penelitian}

Peralatan yang digunakan dalam penelitian ini yaitu: mesin PCR; unit elektroforesis; dan UV transilluminator.

Ikan uji dalam penelitian ini adalah ikan koi (Cyprinus carpio koi). Sedangkan bahan yang digunakan adalah $P C R$ beads (taq polimerase, d NTP, buffer Mg 2+) (Ready-to-go PCR beads dari GE healt care), 2 primer yaitu KHV. (KHV-Gilad):

5'-GACGACGCCGGA GACCTTGTG-3' dan

CACAAGTTCAGTCT GTTCCTCAAC-3' dan (KHV-TK: 5'-GGGTTACCTGTACGAG-3' dan 5'-CACCCAGTAGAT TATG ${ }^{\prime} 3^{\circ}$; gel agarosa, etidium bromida $10 \mathrm{mg} / \mathrm{ml}$, tangga DNA, Loading dye, TBE Buffer, dan air miliopore.

\section{Pengambilan dan Penanganan Sampel}

Sampel ikan (C. Carpio koi) yang digunakan dalam penelitiannj diambil dari lokasi budidaya yang ada diKabupaten Kepulauan Sangihe (Tahuna). Junlaly sampel 10 ekor ikan dengan ukuran panjâng rata-rata 6-13 cm. Sampel ikan ditangkap secara acak dengan menggunakan serokan sebagai alat tangkap. Ikan yang tertangkapsegera dilakukan pemeriksaan morfologi, meliputi pengamatan warna tubuh, keberadaan bercak dan warna bercak pada tubuh bila ada, produksi lendir, warna insang, perdarahan, dan luka pada bagian tubuh. Selanjutnya sampel ikan dibawa ke Laboratorium untuk dianalisis.

\section{Ekstrasi DNA}

Ekstraksi dilakukan dengan cara memotong insang dengan menggunakan silet, kemudian diambil lembar insang bagian dalam yaitu filamen ke 2. Potongan tersebut dihaluskan dengan pestle selama 3 menit, Sentrifus dengan kecepatan 5000 rpm selama 5 menit. Supernatant yang terbentuk (bagian cairan bening di bagian atas) dimasukkan ke tabung epindorf $1 \mathrm{ml}$.

\section{Penyiapan Larutan PCR}

Primer KHV yang digunakan adalah primer KHV Gilad. Kondisi PCR untuk amplifikasi yaitu kondisi I: $95^{\circ} \mathrm{C}$ (5 menit), $94^{\circ} \mathrm{C}$ ( menit), $68^{\circ} \mathrm{C}$ (1 menit), $72^{\circ} \mathrm{C}\left(30\right.$ detik) dan $72^{\circ} \mathrm{C}$ (7 menit). (Gilad et al., 2002). Kondisi-P'CR II yaitu: $95^{\circ} \mathrm{C}$ ( 5 menit), $95^{\circ} \mathrm{C}$ (30 detik), $52^{\circ} \mathrm{C}$ (30 detik), $72^{\circ} \mathrm{C}$ (1 menit) dan $72^{\circ} \mathrm{C}(10$ menit) (Bercovier et al., 2005). Kondisi PCR III: $95^{\circ} \mathrm{C}$ (5 menit), $94^{\circ} \mathrm{C}$ (1 menif), $54^{\circ} \mathrm{C}$ (30 detik), $72^{\circ} \mathrm{C}$ (30 detik) dan $72^{\circ} \mathrm{C}$ (7 menit). Reaksi PCR dapat dilihat pada Tabel 1.

Tabel 1. Reaksi $P C R$ menggunakan Pure Taq Ready to Go Beads

\begin{tabular}{lc}
\hline Bahan & Vol. \\
\hline $\mathrm{H}_{2} \mathrm{O}$ Miliopore $(\mu \mathrm{l})$ & 21 \\
Primer $(\mathrm{E})(\mu \mathrm{l})$ & 1 \\
Primerf(R) $(\mu \mathrm{l})$ & 1 \\
Template DNA $(\mu \mathrm{l})$ & 2 \\
Kolume total & 25 \\
\hline
\end{tabular}

\section{Penyiapan Gel Agarosa Elektroforesis}

1. Siapkan gel agarosa 1\%, 1 g agarosa (untuk $100 \mathrm{ml}$ ) dituangkan ke dalam tabung reaksi. TBE Buffer $1 \mathrm{X}$ ditambahkan ke dalam gelas dan dipanaskan pada $30{ }^{\circ} \mathrm{C}$. Larutan diagitasi dengan menggunakan magnetic stirrer pada kecepatan $500 \mathrm{rpm}$ dan gelas ditutup dengan aluminium foil. Sebelum dituangkan ke dalam cetakan gel dicampurkan dengan Ethidium Bromida $(10 \mathrm{mg} / \mathrm{ml})$ sebanyak $3 \mu \mathrm{l}$. Gel dituangkan ke dalam cetakan (sisir telah terpasang) dan biarkan mengeras selama 30 menit.

2. Masukkan larutan PCR ke dalam lubanglubang yang telah tersedia di permukaan gel agarosa dengan terlebih dahulu dicampur dengan loading dye disertakan juga kontrol positif, kontrol negatif dan marker DNA masing-masing sebanyak $1 \mu 1$. Kontrol positif $(+)$ merupakan produk PCR yang mengandung DNA KHV.

3. Setelah semua sampel disuntikkan, tutup elektroforesis dipasang dan daya dihidupkan dengan tegangan listrik di atur pada $150 \mathrm{~V}$, selama 30 menit. 


\section{Pembacaan Hasil}

Gel Agarosa direndam pada larutan Ethidium bromide $(5 \mu \mathrm{g} / \mathrm{ml})$ selama 20 menit. Hasil PCR dalam gel diamati dengan menggunakan UV transiluminator dan program Gel Doc untuk melihat adanya perpendaran. Hasil menunjukkan $\mathrm{KHV}(+)$ bila terlihat perpendaran pita DNA, jika $\mathrm{KHV}(-)$ bila tidak terlihat perpendaran pita DNA. Hasil selanjutnya didokumentasikan.

\section{HASIL DAN PEMBAHASAN}

Berdasarkan hasil pengujian menggunakan metode PCR diperoleh hasil visualisasi gel electrophoresis yang menunjukan perpendaran pita DNA (Gambar 1), Perpendaran pita DNA pada semua sampel yang diperiksa dengan kondisi PCR III ini mengindikasikan bahwa semua sampel telah terinfeksi virus KHV.

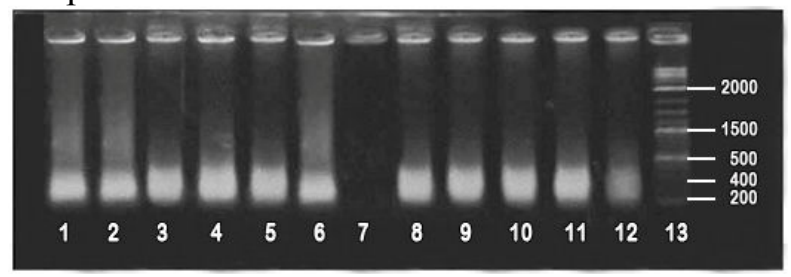

Gambar 1 Hasil Visualisasi Elektroforesis agarosa sampel Sangihe

Ket: $1-5 ; 8-12=$ Sampel ikan koi, $6=$ kontrol positif, $7=$ kontrol negatif, $13=$ marker.

Diagnosa KHV juga dilakukan dengan pemeriksaan morfologi yang menampilkan basil bahwa 3 dari 10 sampel yang digunak an menunjukkan gejala-gejala klinis terserang $K \mathrm{KV}$, dengan tanda-tanda sebagai berikut: mata pucat, insang diselubungi gumpalan lendir putih akibat produksi lendir yang berlebihan (Gambar 3). Sampel lainnya walaupun secara morfblogi tidak menunjukkan gejala-gejala klinis tetapi terindikasi terinfeksi KHV dengan hasil pemeriksaan PCR.

Gejala-gejala klinis infeksi KHV ini sejalan dengan yang dikemukakan oleh Taukhid et al., (2004), dimana serangan KHV ditandai oleh insang bepwarna pucat dan pada infeksi berat terjadi kerusakan jaringan insang serta produksi lendiryang berlebihan pada organ insang. Produksi lendir yang berlebihan pada akhirnya akan menyebabkan keringnya insang dan menimbulkan iritasi yang selanjutnya menyebabkan insang rentan terhadap infeksi oleh bakteri maupun jamur. Infeksi oleh patogen-patogen ikutan ini dikenal dengan infeksi sekunder. Kematian masal ikan akibat KHV pada akhirnya bukan hanya disebabkan oleh virus KHV tapi merupakan kombinasi dengan patogen lain seperti bakteri dan jamur yang memperparah infeksi awal/primer oleh virus KHV (Hendrick et al., 2000).

Hasil penelitian ini mengindikasikan KHV telah tersebar di Sangihe. Penyebaran KHV yang semakin meluas karena adanya pengiriman ikan dari daerah yang terinfeksi sebelumnya. Informasi dari petani ikan di Sangihe, sumber benih atau bibit ikan koi yang ada di Tahuna berasal dari Tondano. Sampel dari Sangihe yang positif terinfeksi dapat memberikan peluang KHV dapat menyebar melalui benih karena danau Tondano merupakan salah satu sentra utama budidaya serta pembenihan ikan koi.

Berdasarkan hasil wawancara dengan petani ikan di lokasi pengambilan sampel, produksi ikan koi dan ikan mas saat initelah mengalami penurunan yang diakibatkan bleh kejadian kematian masal ikan akibat penyakit yang diduga kuat disebabkan oleh KHV berdasarkan tandatanda klinis yang diperlihatkan. Akibat dari terjadi kematian mással, petani ikan telah melakukan upaya antisipasi yakni dengan menurunkan padat tebar terutama pada saat pergantian musim. Ada juga petani yang telah menghentikan usaha bydidaya baik ikan koi maupun ikan mas.

Kehadiran KHV pada ikan koi dapat disebabkan oleh kualitas lingkungan yang buruk. Lingkungan merupakan salah satu hal yang perlu diperhatikan dalam kegiatan budidaya. Perubahan lingkungan dapat menyebabkan munculnya suatu penyakit termasuk penyakit KHV. Perubahan lingkungan dapat di lihat ketika terjadi perubahan cuaca dari musim panas ke musim hujan maupun sebaliknya yang dapat mempengaruhi perubahan suhu perairan. Suhu sangat mempengaruhi perkembangan KHV. Hal ini sesuai dengan yang dikatakan oleh Wedemeyer (1996), bahwa suhu merupakan faktor penting yang sangat berpengaruh pada perkembangan dan tingkat keganasan dari penyakit KHV.

Perubahan suhu secara tiba-tiba dapat berpengaruh terhadap organisme budidaya karena hal ini dapat menyebabkan stress pada ikan dan membuat pertahanan tubuh ikan terhadap penyakit menurun. Ikan akan stress dan kondisi fisiknya akan menjadi lemah sehingga mudah terserang oleh penyakit KHV.

Menurut Hendrick et al., (2000) suhu optimal perkembangan KHV yang dapat menyebabkan kematian adalah $18-27^{\circ} \mathrm{C}$. Sebagian besar mortalitas terjadi pada suhu $18-27^{\circ} \mathrm{C}$, dan tidak ada kasus pada suhu $30^{\circ} \mathrm{C}$. Kematian akan berhenti bila suhu berada di bawah atau di atas kisaran normal. Jadi walaupun dengan suhu perairan 
yang normal tapi jika terjadi perubahan cuaca memberi dampak perubahan suhu perairan yang besar antara $18-27^{\circ} \mathrm{C}$ dapat memicu terjadinya serangan KHV. Menurut Gilad et al., (2003), perubahan suhu air dari $13^{\circ} \mathrm{C}$ menjadi $25^{\circ} \mathrm{C}$ telah mengakibatkan kematian masal dalam waktu singkat dari ikan.

Merubah suhu sampai batas toleransi KHV dapat menghambat munculnya gejala klinis. Hendrick et al., (2004) menyatakan bahwa replikasi KHV dapat terjadi pada suhu $20-25{ }^{\circ} \mathrm{C}$ dan pada suhu $30{ }^{\circ} \mathrm{C}$ dan $4{ }^{\circ} \mathrm{C}$ tidak menunjukan pertumbuhan dan pada suhu $10{ }^{\circ} \mathrm{C}$ menunjukan pertumbuhan yang minimal.

Selain faktor lingkungan, sistem budidaya juga mempengaruhi penyebaran suatu penyakit. Umumnya kolam yang digunakan untuk budidaya di Sangihe, menggunakan sistem pengairan secara seri. Sistem pengairan ini menggunakan pintu pengeluaran air pertama sebagai pintu pemasukkan air untuk kolam berikutnya. Kelemahan dari pengaturan sistem pengairan kolam seperti ini ialah apabila terjadi penurunan kualitas air pada kolam di bagian awal akan sangat mempengaruhi semua kolam berikutnya. Demikian pula apabila terjadi wabah pada kolam bagian awal, maka penyakit akan menyebar dengan cepat pada kolam-kolam berikutnya mengikuti aliran air.

\section{Pencegahan dan Pengendalian KHV}

KHV telah menyebar ke berbagai, tempat dan menyebabkan kerugian yang sapgat besar dalam kegiatan produksi budidaya ikân koi dan mas di Indonesia. Untuk daerah yang terinfeksi KHV, upaya awal dapat dilakukan iatah pemusnahan ikan-ikan yang telah terinfeksi virus KHV. Upaya pencegahan dapat dilakukan dengan vaksinasi sebagai untuk menoicy sistem pertahanan tubuh secara spesifik (Yasumoto et al. 2006). Vaksin juga dapat digunakan sebagai upaya untuk pengendalian hama dan penyakit. Vaksin yang digunakan untuk mengendalikan penyakit KHV adalah KV3 (Anonim, 2009). Cara melemahkan virus yaitu dengan UV radiasi. Vaksin KV3 mudah digunakan, harganya murah dan tingkat keberhasilan $90 \%$ dan hanya digunakan untuk ikan mas dan ikan koi.

Selain itu, sifat virus herpes yang berasosiasi kuat dengan sel sulit ditanggulangi. Langkah pencegahan dapat dilakukan dengan vaksinasi yaitu berupa vaksin konvensional dan vaksin rekombinan. Vaksin konvensional diberikan berupa virus dilemahkan maupun dimatikan. Se- dangkan vaksin rekombinan merupakan hasil rekayasa genetika di mana sekuen gen virus yang bersifat imunogenik disisipkan ke plasmid dan di propagasi pada bakteri. Hasil analisisnya menunjukan gen yang di bawa oleh vaksin terekspresi pada ikan yang di vaksinasi dan setelah di uji menunjukan tingkat keberhasilan hidup $95 \%$. (Anonim, 2010).

Upaya lain yang dapat dilakukan ialah dengan uji PCR secara dini terhadap ikan sebelum didistribusikan ke daerah lain. Upaya ini memang memerlukan konsistensi, dukurgan dána dan metode lain yang lebih efektif tanpa-méngorbankan para pembudidaya serta penerapan biosecurity dalam kegiatan budidaya (Adisucipto, 2009), sebagai rangkaian usaha untuk mencegah dan mengurangi peluang masyknya suatu penyakit ke dalam sistem budidaya dan mencegah penyebaran dari satu tempat ke tempat lain yang masih bebas. Prinsip dasar biosecurity ialah isolasi dan desinfeksi.

Metode karantina dapat juga dilakukan dalam upaya pencegahan penyebaran penyakit KHV. Hartmaan et al., (2008) menyatakan bahwa, tindakan karantina merupakan metode yang paling sering digunakan untuk menghindari masuknya KuV ke dalam populasi ikan mas yang sudah lama dipelihara. Penerapan metode karantina dilakukan untuk ikan yang masuk dan keluar. Waktu yang diperlukan untuk tindak karantina ini minimal 30 hari.

\section{KESIMPULAN}

Hasil deteksi menyimpulkan bahwa keberadaan KHV pada ikan koi (Cyprinus carpio koi) yang dibudidayakan di Kabupaten Kepulauan Sangihe (Tahuna) menunjukkan bahwa semua sampel ikan positif terinfeksi virus KHV. Hasil pemeriksaan ini ditandai dengan adanya perpendaran pita sampel ikan yang sama dengan kontrol positif pada produk PCR hasil visualisasi elektroforesis.

\section{DAFTAR PUSTAKA}

Anonim. 2009. KV3 Vaccine againts KHV. http://www. kovax.co.il/ dynamic data/KV3General.asp. [diunduh 25 Februari 2012].

Anonim. 2010. Vaksin KHV. http://lppm.ipb.ic.id/indeks. vaksin [diunduh 27 Februari 2012].

Adisucipto. 2009. Ikan Mas dan KHV. adisucipto.com/ fish-health/ikan-mas-dan-khv.html.

Bercovier H, Y Fishman, R Nahary, S Sinai, A Zlotkin, M Eyngor, O Gilad, A Eldar, RP Hedrick. 2005. Cloning of the koi herpesvirus (KHV) gene encoding 
thymidine kinase and its use for a highly sensitive PCR based diagnosis. Bio. Med. Central Microbiology 2005, 5: 13.

Gilad O, S Yun, KB Andree, MA Adkison, A Zlotkin, H Bercovier, A Eldar, RP Hedrick. 2002. Initial characteristics of koi herpesvirus and development of a polymerase chain reaction assay to detect the virus in koi, Cyprinus carpio koi. Diseases of Aquatic Organisms, Vol. 48: 101-108, 2002.

Gilad O, S Yun, MA Adkison, K Way, NH Willits, H Bercovier, and RP Hedrick. 2003. Molecular comparison of isolates of an emerging fish pathogen, koi herpesvirus, and the effect of water temperature on mortality of experimentally infected koi. J. Gen. Virol., 84: 2661-2667.

Haenan OLM, K Way, SM Bergmann, E Ariel. 2004: The emergence of koi herpesvirus and its significance to european to aquakulture. Bulletin of the European Association of Fish Pathologists, 24, 293-307.

Hartman KH, RPE Yanong, BD Petty, R Francis-Floyd, and AC Riggs. 2008. Koi Herpes Virus (KHV) Disease. University of Florida. http://edis.ifas.ufl.edu.

Hendrick RP, O Gilad, S Yun, JV Spangenberg, GD Marty, RW Nordhausen, MJ Kebus, H Bercovier, and A Eldar. 2000. A herpesvirus associated with mass mortality of juvenile and adult koi, a strain of common carp. J. Aquat. Anim. Health, 12: 44-57.

Hendrick RP, O Gilad, S Yun, TS McDowell, TB Waltzek, GO Kelley, MA Adkison. 2004. Initial
Isolation and Characterization of a herpes-like virus (Khv) from koi. In: Report of International Workshop on Koi Herpes Virus.

Mudjiutami et al. 2009. Uji Toleransi Strain Ikan Mas Terhadap KHV. http://www.dkp.go.id

Perelberg A, M Smirnov, M Hutoran, A Diamant, Y Bejerano, and $M$ Kotler. 2003. Epidemiological description of a new viral disease afflicting cultured Cyprinus carpio in Israel. The Israel Journal of Aquacultur

Sunarto A, A Rukyani, and T Itami. 2005. Indonesian Experience on the Outbreak of Koi Herpesvirus in Koi and Common Crap (Cyprinus carpio). Bull, Fish. Res. Agen. Japan, Supp 2: 15-21

Taukhid, A Sunarto, I Koesharyani, H Supriyadr, dan L Gardenia. 2004. Strategi pengendalian penyakit koi herpesvirus (KHV) pada ikan mas dan koi. Laboratorium Riset Kesehatan Ikan, Badan Riset Kelautan dan Perikanan, Jakarta. Makalah dipresentasikan pada Workshop pengendalian penyakit Koi Herpesvirus (KHV) pada budidaya ikan ât tavar, Bogor. 28 September 2004.

Yasumoto S, T Yosimûra and T Miyazaki (2006). Oral Immunization of Common Carp with a Liposome vaccine containing Aeromonas Hydrophila antigen. Fish Pathol, 41) 45-49.

Wedemeyer GA. 1996. Physiology of Fish in Intansive Culture Sistem. Chapman and Hill.

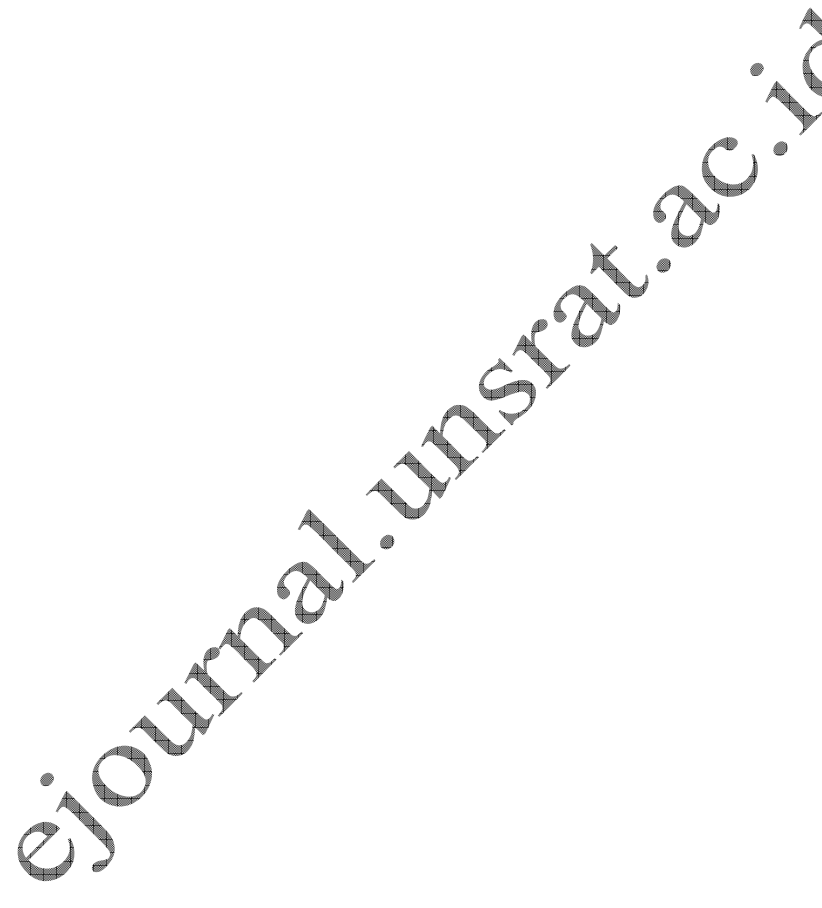

